\title{
1.3 A SYNTHETIZED MODEL OF DEVELOPMENT OF LOGISTICS ORGANIZATION AND COMPANY LIFECYCLE
}

\begin{abstract}
Summary: The aim of this study is to map the evolution of logistics organization in companies along their lifecycle. According to our hypothesis different configurations of logistics organization appear at the different periods of companies' life. For the purpose of this study we used Larry E. Greiner's organizational growth model, which was first published in 1972, and actualized in 1998 by the author and the model for logistics organization of D. J. Bowersox et al., published in 2002. We drew a parallel between the two models using the similarities of the corresponding stages of development. We tested the parallelism on a sample of 97 Hungarian companies from the industrial and commercial sectors. We assigned each sample company to a stage of the Greiner model using a fuzzy classification method, then we analyzed the characteristics of logistics organizations for each growth stage. The results of the empirical analysis supported the parallelism between the two models. It can be used as a basis for further studies in this topic and also in practice for management consulting in the fields of organizational development and logistics.
\end{abstract}

Keywords: company lifecycle, organizational growth, logistics, organization

\section{INTRODUCTION}

Logistics organization is an important issue of international logistics literature. All authors agree in that logistics organization should suit to the internal and external environment of the company. Internally it means harmony with the company organizational structure and strategy, externally it means exploiting possibilities and meeting market expectations. Logistics operations should be effective and efficient in the same time. This means that growing companies need different logistics organizations as they go through their lifecycle.

Organizational growth models give detailed descriptions on company characteristics in each stage of their lifecycle, but do not give details on the different company functions - like logistics. In our opinion each stage of development require different contribution from the logistics function and different logistics organizational structure as well. Defining ideal logistics organization to each stage may be useful for developing companies to form their logistics function.

\section{LITERATURE REVIEW}

\subsection{ORGANIZATIONAL GROWTH}

Researchers of organizational development agree that growth of companies can be separated to well-defined stages (Greiner 1972, Churchill-Lewis 1983, Quinn-Cameron 1983, Miller-Friesen 1984, Baird-Meshoulam 1988, Kazanjian 1988, Timmons 1990, Milliman et al. 1991, Adizes 1992, Hurst 1995). Each stage can be characterized by behaviour in the market, organization and management problems. Researchers also agree that it is advantageous for a company if the manager is aware of the logic of growth models and the position of his/her company in the models. According to Göbölös and Gömöri (2004) this makes management more conscious and helps to prepare for future changes and probable 
management problems. Tatár et al. (2012) emphasize the importance of managing the revolutionary stages of lifecycle that determine the further development of the company.

For the purpose of this study, we used Larry E. Greiner's organizational growth model, which was first published in 1972, and actualized in 1998 by the author. It is one of the most often cited company growth models, and it is widely used in practice by management consultant companies. The main strengths of the model are that it is universal regarding sector and size, it is detailed enough for our purposes, and its stages are relatively well defined and characteristic.

Figure 1 shows the evolutionary and revolutionary periods defined by Greiner. Although Greiner interpreted one phase as a sequence of an evolutionary phase and a crisis, in our point of view crises have so unique characteristics that their interpretation as a separate phase is reasonable. In the following part of the article we use the abbreviations of the phases (for example 1P for Phase 1 or $3 \mathrm{C}$ for Crisis 3) when referring to a phase.

Figure 1: Growth phases defined by Greiner (1972 and 1998)

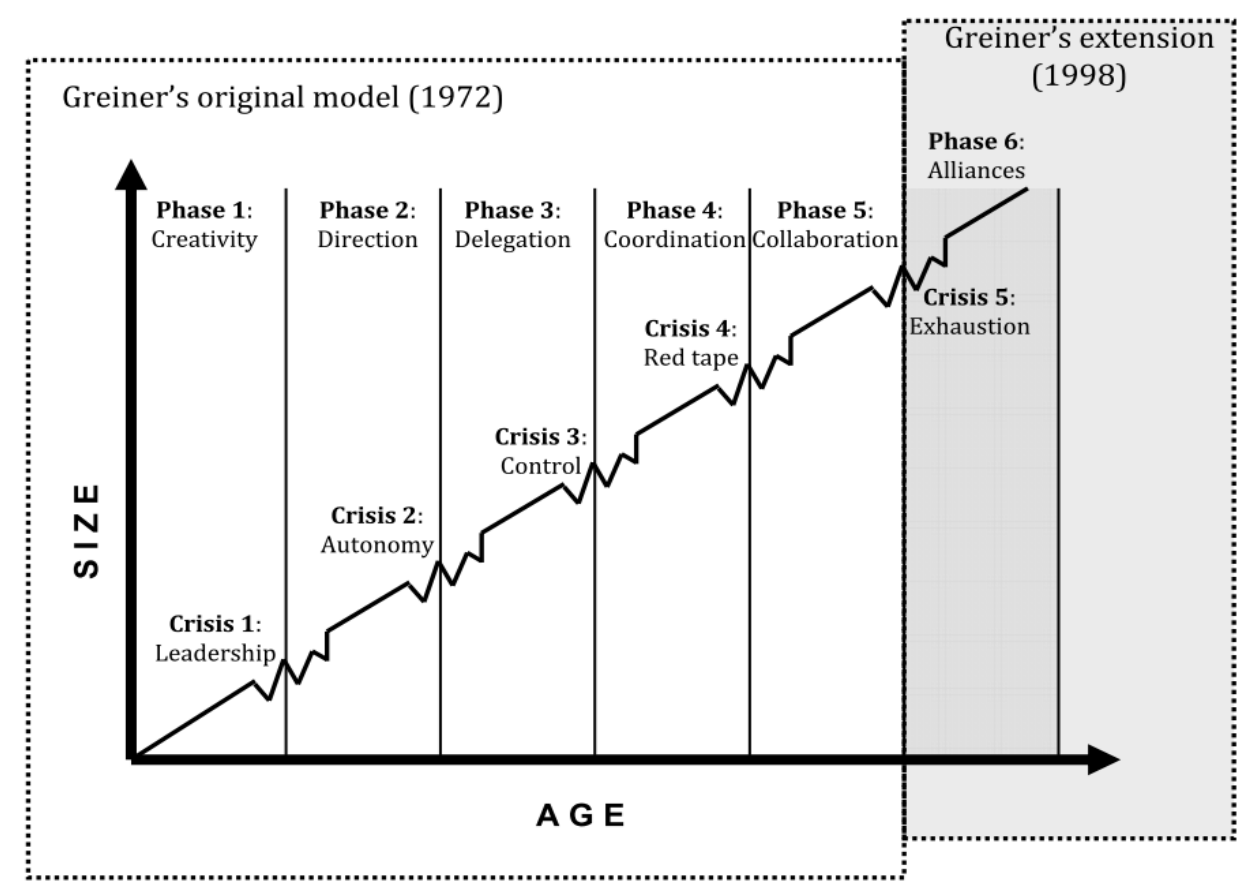

Source: own figure based on Greiner $(1972,1998)$

We have no possibility to give details of each phase in this study due to limitations on length but we present the most important features of them from the point of view of this study in Table 3.

\subsection{LOGISTICS ORGANIZATION}

Logistics organizational structures are discussed from different points of view in literature but basic models appear in most works. We reviewed four models for typical forms of logistics organization: Lambert et al. (1998), Bowersox et al. (2002), Frazelle (2002) and Rushton et al. (2006). Table 1 shows the structures discussed by these authors.

We found Bowersox's approach is the most suitable for the purposes of this study as it is an evolutionary approach in contrast with Frazelle's, and it is more detailed than the other two evolutionary models. Dividing the functional integration into three steps makes it more suitable for finding correspondence between the growth phases and the logistics organization structures as integration can go on gradually. Therefore, we use the Bowersox model as a basis and complete it with the ideas of the other three authors. 
Table 1: Logistics organizational structure types in logistics literature - summary table

\begin{tabular}{|c|c|c|c|}
\hline $\begin{array}{c}\text { Bowersox-Closs- } \\
\text { Cooper (2002) } \\
\end{array}$ & $\begin{array}{c}\text { Frazelle } \\
(2002) \\
\end{array}$ & $\begin{array}{l}\text { Lambert-Stock- } \\
\text { Ellram (1998) }\end{array}$ & $\begin{array}{c}\text { Rushton-Croucher- } \\
\text { Baker (2006) }\end{array}$ \\
\hline $\begin{array}{l}\text { Phase } 0 \text {. Fragmented } \\
\text { functional structures }\end{array}$ & - & - & $\begin{array}{l}\text { Traditional } \\
\text { organizational structure }\end{array}$ \\
\hline $\begin{array}{l}\text { Phase 1. Functional } \\
\text { aggregation } 1\end{array}$ & - & - & s r a r a \\
\hline $\begin{array}{l}\text { Phase } 2 \text {. Functional } \\
\text { aggregation } 2\end{array}$ & $\begin{array}{l}\text { Functional } \\
\text { organization }\end{array}$ & - & - \\
\hline \multirow{2}{*}{$\begin{array}{l}\text { Phase } 3 \text {. Functional } \\
\text { aggregation } 3\end{array}$} & $\begin{array}{l}\text { Integrated logistics } \\
\text { organization }\end{array}$ & \multirow{2}{*}{$\begin{array}{l}\text { Logistics as a } \\
\text { function }\end{array}$} & \multirow{2}{*}{ Functional structure } \\
\hline & $\begin{array}{l}\text { Global logistics } \\
\text { organization }\end{array}$ & & \\
\hline \multirow{2}{*}{$\begin{array}{l}\text { Phase 4. Process } \\
\text { integration }\end{array}$} & Process organization & $\begin{array}{l}\text { Logistics as a } \\
\text { program }\end{array}$ & $\begin{array}{l}\text { Process-driven } \\
\text { organizational structure }\end{array}$ \\
\hline & Matrix organization & $\begin{array}{l}\text { Logistics as a matrix } \\
\text { organization }\end{array}$ & $\begin{array}{l}\text { Matrix organizational } \\
\text { structure }\end{array}$ \\
\hline $\begin{array}{l}\text { Phase } 5 . \text { Virtuality } \\
\text { and organizational } \\
\text { transparency }\end{array}$ & $\begin{array}{l}\text { Distributed logistics } \\
\text { organization }\end{array}$ & - & - \\
\hline- & $\begin{array}{l}\text { Business unit logistics } \\
\text { organization }\end{array}$ & - & - \\
\hline
\end{tabular}

Source: own table based on Bowersox et al. (2002), Lambert et al. (1998) and Rushton et al. (2006)

Stage 0. Fragmented functional structures

These structures are typical for traditional or young organizations. Logistics activities are dispersed to Marketing, Manufacturing and Finance functions. This fragmentation means the lack of cross-functional coordination which results in distortion or delay of information, duplication and waste. (Bowersox et al. 2002) Lines of communication are unclear so it is often impossible to optimize the different logistics sub-functions for effectiveness and efficiency. (Rushton et al. 2006)

\section{Stage 1. Functional aggregation 1}

The first step towards integration is grouping the logistical activities within the original function. The overall organizational structure and hierarchy do not change significantly. Typical aggregations in this phase are for example:

- marketing: aggregation of customer service activities

- manufacturing: aggregation of materials management activities.

This organization still does not provide integrated inventory management and does not handle trade-offs between inventory and transportation costs. (Bowersox et al. 2002)

\section{Stage 2. Functional aggregation 2}

Logistics as a separated function appears in the organizational chart with own authority and responsibility. The logistics department usually involves physical distribution and material management at this stage. It still does not include some important logistical activities such as procurement or order processing, these tasks are performed by other functions. Limited communication and coordination between functions result in the lack of efficiency. (Bowersox et al. 2002) Another weakness is that since the logistics department performs only transportation and warehousing activities, it aims to minimize only these costs. This can lead to growing overall logistics costs and service level problems due to trade-offs. (Frazelle 2002)

Stage 3. Functional aggregation 3

In this phase of aggregation, the aim is to integrate all possible logistical activities within the boundaries of a single functional unit and exploit synergies. The logistics function includes planning and operations as well, so logistics get into strategic level. (Bowersox et al. 
2002) Advantage of the integration is that it can handle trade-offs, and overall logistics cost, service level and efficiency can be optimized. Responsibility is delegated to a Chief Logistics Officer (CLO). (Frazelle 2002) Global logistics organization is an extended version of integrated logistics organization, which is responsible for all logistical activities of a company operating in more than one regions. (Frazelle 2002)

Despite the integration, there are still problems, generated by the characteristics of functional organizations:

- overall company performance is still not optimal, considering there is no full cooperation between the functions. (Lambert et al. 1998)

- it focuses on internal operations, the customers' expectations get less emphasis than needed. (Rushton et al. 2006)

\section{Stage 4. Process integration}

Process-oriented organizations are able to reach a higher level of service and productivity than functional organizations. Process management appears in the following two types of organization.

- In process organization or process-driven organization, the core business process defines its requirements for logistical activities, which are performed by the logistics function. All activities are driven by the key performance objectives of the core process, the other processes only service them. (Frazelle 2002, Rushton et al. 2006)

- Matrix organization is a combination of functional and process organization. Usually planning is the responsibility of the process manager, while operations are the responsibility of the functional manager. This provides high-level customer service through process management and cost efficiency through functional optimization. (Frazelle 2002, Lambert et al. 1998, Rushton et al. 2006)

Process-oriented organizations also have to face problems and dilemmas:

- How can an organization be structured so that it can manage a process as complex as global logistics without becoming overly bureaucratic? (Bowersox et al. 2002)

- It is impossible to meet perfectly the demands of service quality and efficient operation at the same time. Depending on the abilities of the functional and process management one of the goals will not be reached. (Frazelle 2002)

- Coordination gets complicated due to functional egoism, so running such an organization requires constant support of top-level management. (Lambert et al. 1998, Rushton et al. 2006)

Stage 5. Virtuality and organizational transparency

These are the organizations of the future, but some companies (for example Dell) already apply this structure. Logistics operations are dispersed to different functions or processes under the coordination of a CLO. Advanced IT systems provide coordination through common database and information sharing, making optimization possible not only in company level but across companies in the supply chain. Performing operations locally provides the best competences and flexibility. (Frazelle 2002, Bowersox et al. 2002)

\subsection{SYNTHESIS OF THE TWO MODELS}

\subsubsection{Organizational growth as a different context for development of logistics}

All authors cited in the previous section - except for Frazelle - defined the different organizational structures as stages of historical development. They assigned each structure to the era they had appeared and had been applied by big US companies. The way of development is shown in Table 2. 
Table 2: Development of logistics organization

\begin{tabular}{|l|l|}
\hline Phase of development & Representative era \\
\hline Stage 0. Fragmented functional structures & Up to the 1950s \\
\hline Stage 1. Functional aggregation 1 & Late 1950s - early 1960s \\
\hline Stage 2. Functional aggregation 2 & Late 1960s - early 1970s \\
\hline Stage 3. Functional aggregation 3 & $1980 \mathrm{~s}$ \\
\hline Stage 4. Process integration & $2000 \mathrm{~s}$ \\
\hline Stage 5. Virtuality and organizational transparency & Presently and in the future \\
\hline
\end{tabular}

Source: own table based on Bowersox et al. (2002 p.521-530), Lambert et al. (1998 p.437-438) and Rushton et al. (2006 p.164-170)

Interpreting organizational solutions as historical development is only one point of view that applies only to the most developed companies of one of the most developed economies of the world. This approach excludes companies that stopped growing at small or medium size or companies that are in the beginning of their lifecycle.

In our opinion, the stages of historical development correspond with the stages of company development. In new, small and not logistics-intensive companies (as the ones in the Creativity or Leadership phase) logistics-related activities are dispersed in the organization, often performed together with other tasks by the same employee. As the company grows, these activities are more consciously organized, and there is a growing need for efficient and transparent operations. This forces companies to step into the phases of functional aggregation 1 and 2, typically when the company is in the phase of Direction.

Full functional integration (Stage 3) is reached by large or very consciously managed middle-sized companies, where the logistics function is fully developed and tasks are cleared. This is usually in the Delegation phase or later.

Process integration is the solution when companies aim to rationalize their operations and focus on supply chain partnerships typically in the phase of Coordination. There is large emphasis on inter-organizational management at this stage. Logistics function is often expanded and is referred to as SCM function.

Virtual organizations are applied by few companies so far, but it can be a good solution for the challenges of the Collaboration phase. The solution lies in advanced IT systems that provide coordination within and between companies. The presence of logistics experts are beneficial in the fields of supplier relationship management, CRM, customer service management, demand management, order fulfilment, manufacturing flow management and product development. However, this phase of development, like virtual organizations is a subject of recent researches.

Based on the conjecture that the development of logistics organization is parallel with company growth, we attempted to link a growth model with the theory of logistics organization. The new, joint model can help to identify the ideal logistics organization with the help of growth phases. The models of Greiner and Bowersox et al. seem suitable for this purpose.

\subsubsection{Linking the two models}

The two models show several similarities. Both of them are evolutionary models, and they are similarly detailed. Both of them give a description to each stage of development using the same types of attributes (size, organizational questions, tasks assigned to operational or 
strategic level, delegation, use of planning and controlling methods, information flow). The correspondence of the two models is shown in Table 3.

\section{Table 3: Correspondence between Phases of growth (Greiner) and logistics organization (Bowersox)}

\begin{tabular}{|c|c|c|c|}
\hline $\begin{array}{l}\text { Organization } \\
\text { (Bowesox et al.) }\end{array}$ & $\begin{array}{c}\text { Characteristics of logistics } \\
\text { organization }\end{array}$ & $\begin{array}{c}\text { Characteristics of growth } \\
\text { phase }\end{array}$ & $\begin{array}{l}\text { Phase of growth } \\
\text { (Greiner) }\end{array}$ \\
\hline $\begin{array}{l}\text { Stage } 0 . \\
\text { Fragmented } \\
\text { functional } \\
\text { structures }\end{array}$ & $\begin{array}{l}\text {-No independent logistics } \\
\text { organization } \\
\text {-Logistics activities dispersed to } \\
\text { other functions } \\
\text {-Duplication of tasks } \\
\text {-Lack of functional coordination }\end{array}$ & $\begin{array}{l}\text { - No independent functional units } \\
\text {-Functions integrated to core } \\
\text { activity } \\
\text {-Functional objectives not } \\
\text { determined }\end{array}$ & $\begin{array}{l}\text { Phase 1: } \\
\text { Creativity }\end{array}$ \\
\hline $\begin{array}{l}\text { Stage } 1 . \\
\text { Functional } \\
\text { aggregation } 1\end{array}$ & $\begin{array}{l}\text {-Grouping of some logistics tasks } \\
\text { within the original function } \\
\text { - No integrated inventory } \\
\text { management }\end{array}$ & $\begin{array}{l}\text {-Formulating functional units } \\
\text {-Functional and company } \\
\text { objectives not harmonized }\end{array}$ & $\begin{array}{l}\text { Crisis 1: } \\
\text { Leadership }\end{array}$ \\
\hline \multirow[b]{2}{*}{$\begin{array}{l}\text { Stage } 2 . \\
\text { Functional } \\
\text { aggregation } 2\end{array}$} & \multirow{2}{*}{$\begin{array}{l}\text {-Independent logistics unit } \\
\text {-Involves physical distribution and } \\
\text { material management } \\
\text {-Limited communication between } \\
\text { functions } \\
\text { - No company-level optimization }\end{array}$} & $\begin{array}{l}\text {-Functional structure } \\
\text {-Basics of controlling and } \\
\text { planning } \\
\text {-Middle line managers }\end{array}$ & $\begin{array}{l}\text { Phase 2: } \\
\text { Direction }\end{array}$ \\
\hline & & $\begin{array}{l}\text {-Executive is the only decision- } \\
\text { maker } \\
\text { - Communication between } \\
\text { functions only through the } \\
\text { executive - decrease in } \\
\text { performance due to overload }\end{array}$ & $\begin{array}{l}\text { Crisis 2: } \\
\text { Autonomy }\end{array}$ \\
\hline \multirow{2}{*}{$\begin{array}{l}\text { Stage } 3 . \\
\text { Functional } \\
\text { aggregation } 3\end{array}$} & \multirow{2}{*}{$\begin{array}{l}\text { - Most logistics activities done in } \\
\text { one unit } \\
\text { - Logistics on strategic level } \\
\text { - Company-level optimization in } \\
\text { logistics } \\
\text { - Logistics information system } \\
\text { - Limited cooperation with other } \\
\text { functions }\end{array}$} & $\begin{array}{l}\text { - Delegation of decision-making } \\
\text { to functional managers } \\
\text {-Faster and more efficient } \\
\text { operations and information flow }\end{array}$ & $\begin{array}{l}\text { Phase 3: } \\
\text { Delegation }\end{array}$ \\
\hline & & $\begin{array}{l}\text { - Lack of control over functional } \\
\text { units } \\
\text {-Inconsistence between } \\
\text { company and functional } \\
\text { strategy }\end{array}$ & $\begin{array}{l}\text { Crisis 3: } \\
\text { Control }\end{array}$ \\
\hline \multirow{2}{*}{$\begin{array}{l}\text { Stage } 4 \text {. Process } \\
\text { integration }\end{array}$} & \multirow{2}{*}{$\begin{array}{l}\text {-Activities driven by the key } \\
\text { performance objectives of the } \\
\text { core process } \\
\text { - Intensive information flow } \\
\text { between functions } \\
\text {-High-leve service and } \\
\text { productivity } \\
\text {-Conflicts between process and } \\
\text { functional objectives } \\
\text { - Risk of being overly bureaucratic } \\
\text {-Coordination problems }\end{array}$} & $\begin{array}{l}\text {-Transparent structure and } \\
\text { controlling system } \\
\text {-Fulfilment of company goals } \\
\text { precisely tracked } \\
\text { Effective and efficient operation }\end{array}$ & $\begin{array}{l}\text { Phase 4: } \\
\text { Coordination }\end{array}$ \\
\hline & & $\begin{array}{l}\text {-Growing bureaucracy } \\
\text {-Conflicts between management } \\
\text { and operations } \\
\text {-Slowing decision-making, } \\
\text { decreasing efficiency }\end{array}$ & $\begin{array}{l}\text { Crisis 4: } \\
\text { Red tape }\end{array}$ \\
\hline $\begin{array}{l}\text { Stage } 5 . \\
\text { Virtuality and } \\
\text { organizational } \\
\text { transparency }\end{array}$ & $\begin{array}{l}\text {-Disintegration of logistics } \\
\text { processes } \\
\text {-Developed IT support } \\
\text { - Virtual integration and physical } \\
\text { dispersion } \\
\text {-Integration with other functions } \\
\text { and across the supply chain }\end{array}$ & $\begin{array}{l}\text {-Efficient cooperation between } \\
\text { organizational units }\end{array}$ & $\begin{array}{l}\text { Phase 5: } \\
\text { Collaboration }\end{array}$ \\
\hline
\end{tabular}

Source: own table based on Bowersox et al (2002) and Greiner (1972) 


\section{MATERIAL AND METHOD}

\subsection{COMPANY SAMPLE}

We have tested the parallelism of the two models on a sample of Hungarian companies. The observed companies were chosen by field of activity, where logistics is a relevant but not core activity and therefore the presence of the logistics organization is possible. Regarding to company size the minimum number on FTEs was 10 . The observed companies are active in manufacturing or commerce.

C-level managers of the sample companies filled in a questionnaire in frames of a personal interview. Questionnaires were prepared between February and May 2009, the number of interviews made was 120 . Only 97 of them were analysed due to insufficient answers on critical questions.

The sample involved 49 commercial and 48 manufacturing companies. Nearly half of them (49 companies) is seated in Budapest, the rest of the companies are nearly evenly distributed geographically (21 companies from the western and 27 companies from the eastern part of Hungary).

Most of the companies (85) were founded after 1990, the rest operated as a large socialist company before their privatisation. For examining organic development, the first group is more suitable, since they had the possibility to grow within a market environment. However, these companies are too young for the purpose of this study, as they could not reach a higher phase of growth.

The size of the sample companies does not reflect the distribution of company sizes in the Hungarian economy. The reason for it is the overwhelming presence of micro- and small sized enterprises on the market. A representative sample would have caused the lack of more developed companies in the sample and would have made the examination of later stages of development impossible. Therefore, medium and large sized companies are overrepresented in the sample. The distribution of the companies is the following:

$\begin{array}{lll}\text { Revenue: } & \text { 0-3 billion HUF: } & 67 \\ & \text { 3-15 billion HUF: } & 23 \\ & \text { above } 15 \text { billion HUF: } & 7 \\ \text { Employees: } & \text { 10-49 employees: } & 60 \\ & \text { 50-249 employees: } & 21 \\ & \text { above } 250 \text { employees: } & 16\end{array}$

The organizational structure of the sample companies is also important of our point of view as it affects the structure of logistics organization. Most of the companies have simple structure (39 companies) or functional organization (43 companies). Divisional organization (12 companies) and matrix structure (3 companies) are also represented.

\subsection{RESEARCH METHODOLOGY}

The aim of the questionnaire was to assign the sample companies to the phases of the growth model as precisely as possible, then examine the management and logistics characteristics in each phase. Since we were intent to gain a complex picture of the sample companies, we created three groups of questions: one for general attributes and management (questions no. 1-8 and 10), one for company environment (questions no. 11-18) and one for company logistics (questions no.19-30). We processed and analysed the data of the survey with MS Excel and MINITAB softwares.

The first step of data processing was the assignment of sample companies to Greiner's growth phases (company classification). We used a fuzzy classification method for this 
purpose (Miskolczi-Gábriel 2008, 2012). The classification was based on a group of questions dedicated to the attributes a company should have in each phase of growth. The interviewee had to mark on a four-grade scale, how characteristic are these attributes to their companies. The answers were then converted to fuzzy membership functions by using correspondence matrices in which we defined the relationship between each answer and the membership degree in each phase. The final step was the defuzzification of the membership function with MOM method to get a crisp (the one most typical) result for growth phase.

The second step was the analysis of logistics characteristics of the company based on a group of questions dedicated to logistics. The aim of this step was to check whether the companies classified into a given growth phase show the characteristics of the corresponding stage of logistics organization given in Table 2. We checked the following characteristics:

- existence and type of logistics organization,

- number of employees doing logistics-related tasks,

- logistics related activities done by the companies (number and type),

- location of the tasks above (operational and strategic) in the organizational structure.

\section{RESULTS}

After the classification of companies, we got the result shown in Table 4. Although the medium and large companies were overrepresented in the sample compared to their presence in the Hungarian market, only a few companies were assigned to phases 3P-5C. This was not enough to draw statistically significant conclusions; therefore statements can be only made for phases $1 \mathrm{P}-2 \mathrm{C}$. We give forth the results of phases 3P-5C but as they are only informative data, we mark them with cursive letters.

Table 4: Result of classification

\begin{tabular}{|l|l||l|l|}
\hline Growth phase & No. of companies & Growth phase & No. of companies \\
\hline \hline 1P & 24 & 4P & 3 \\
\hline 1C & 21 & $4 \mathrm{C}$ & 2 \\
\hline & 18 & 5P & 6 \\
\hline 2P & 13 & 5C & 3 \\
\hline 2C & 1 & not classified & 5 \\
\hline 3P & 1 & Total & 97 \\
\hline 3C & \multicolumn{2}{|l|}{}
\end{tabular}

Source: own research

For the existence and type of logistics organization, we got the results shown in Table 5.

Table 5: Logistics organization in the growth phases

\begin{tabular}{|c|c|c|c|c|}
\hline \multirow[b]{2}{*}{ Phase } & \multirow[b]{2}{*}{ No. of companies } & \multicolumn{3}{|c|}{ Logistics organization } \\
\hline & & none & simple & integrated \\
\hline $1 \mathrm{P}$ & 24 & $100 \%$ & $0 \%$ & $0 \%$ \\
\hline $1 \mathrm{C}$ & 21 & $100 \%$ & $0 \%$ & $0 \%$ \\
\hline $2 \mathrm{P}$ & 18 & $78 \%$ & $22 \%$ & $0 \%$ \\
\hline $2 \mathrm{C}$ & 13 & $77 \%$ & $15 \%$ & $8 \%$ \\
\hline $3 P$ & 1 & $100 \%$ & $0 \%$ & $0 \%$ \\
\hline $3 C$ & 1 & $0 \%$ & $100 \%$ & $0 \%$ \\
\hline $4 P$ & 3 & $0 \%$ & $33 \%$ & $67 \%$ \\
\hline $4 C$ & 2 & $0 \%$ & $100 \%$ & $0 \%$ \\
\hline $5 P$ & 6 & $0 \%$ & $17 \%$ & $83 \%$ \\
\hline $5 C$ & 3 & $0 \%$ & $0 \%$ & $100 \%$ \\
\hline
\end{tabular}

Source: own research 
In phases $1 \mathrm{P}$ and $1 \mathrm{C}$ none of the companies have logistics unit, which is in accordance with the characteristics of fragmented structure and functional aggregation 1 (in this case there is still no independent organizational unit for logistics). Logistics organization appears first in phases $2 \mathrm{P}-2 \mathrm{C}$ in the model. It is supported by the results, although the number of companies without logistics unit is still high. From phase 3P results are not reliable but they show the pattern the model suggests as all companies have logistics organization, and from phase $4 \mathrm{P}$ there is a strong presence of integrated logistics. Virtual organization (stage 5) is not present for two reasons: this structure is not common yet, and it is applicable only at global level, while this study involved only the Hungarian affiliates, not global companies as a whole.

Table 6 shows the number of employees performing logistics-related tasks in each phase. The small number of employees in phase 1P explains the lack of organizational unit. Several companies of phases $1 \mathrm{C}-2 \mathrm{C}$ still do not have enough employees doing logistics that would require a separate organizational unit. These companies perform non logistics-intensive activities, therefore logistics do not appear in strategic level. However, the first level of functional aggregation can be completed even in these companies.

Table 6: Number of employees doing logistics in the growth phases

\begin{tabular}{|c|c|c|c|c|}
\hline \multirow{2}{*}{ Phase } & \multirow{2}{*}{ No. of companies } & \multicolumn{3}{|c|}{ Number of employees } \\
\hline & & minimum & maximum & average \\
\hline $1 \mathrm{~F}$ & 24 & 0 & 5 & 2,1 \\
\hline $1 \mathrm{~K}$ & 21 & 1 & 25 & 4,9 \\
\hline $2 \mathrm{~F}$ & 18 & 1 & 30 & 8,1 \\
\hline $2 \mathrm{~K}$ & 13 & 0 & 100 & 13,1 \\
\hline $3 F$ & 1 & 5 & 5 & 5 \\
\hline $3 K$ & 1 & 20 & 20 & 20 \\
\hline $4 F$ & 3 & 60 & 250 & 126,7 \\
\hline $4 K$ & 2 & 4 & 15 & 9,5 \\
\hline $5 F$ & 6 & 18 & 490 & 145,8 \\
\hline $5 K$ & 3 & 100 & 2300 & 850 \\
\hline
\end{tabular}

Source: own research

We also examined the relationship between type of logistics organization and number of employees. According to the results in Table 7, no logistics unit was created under 8 employees. At the same time there were companies with 20 and 25 employees but without organizational unit in logistics. Naturally, functional aggregation 1 could be completed in these companies. Integrated logistics organization can be found in the sample even by an employee number of 20, but the typical number of employees in this group was significantly higher, above 100 people.

Table 7: Number of employees doing logistics in the different types of organization

\begin{tabular}{|c|c|c|c|}
\hline \multirow{2}{*}{$\begin{array}{c}\text { Logistics } \\
\text { organization }\end{array}$} & \multicolumn{3}{|c|}{ Number of employees } \\
\cline { 2 - 4 } & minimum & maximum & average \\
\hline \hline none & 0 & 25 & 3,7 \\
\hline simple & 8 & 70 & 21,5 \\
\hline integrated & 20 & 2300 & 328 \\
\hline
\end{tabular}

Source: own research

We overviewed the presence and position of logistics activities in the company organization. In the following we summarize our findings for the first four phase - where there were enough sample companies to examine.

There were no companies in phases $1 \mathrm{P}$ and $1 \mathrm{C}$ where the name of the unit carrying out logistics activities contained the word "logistics". The typical organizational units doing 
logistics activities were "production", "sales" and "maintenance/engineering" depending on the core activity of the company. The average number of logistics-related employees was 2.1 in $1 \mathrm{P}$ and 4.9 in $1 \mathrm{C}$.

In phase $1 \mathrm{P}$ all of the planning and controlling activities were done by the company manager, employees performed operational tasks. The most often mentioned tasks were the following:

- Operative purchasing

- Providing information on suppliers to production

- Material handling

- Preparation of material for production

- Providing information on production to warehouse
- Quality check

- Packaging, finishing

- Providing information on stocks to sales

- Commission

- Distribution

- Return goods handling

- Waste handling

These tasks were assigned in most cases to the following units:

- production/factory

- sales/commerce

- technical group.

The employees doing logistics were not grouped within these units in $1 \mathrm{P}$, which is in accordance with the description of fragmented functional structures in the Bowersox model.

This organizational structure became a little more sophisticated in 1C where subgroups appeared within the three functions above. The sample companies mentioned the following units:

- purchasing

- warehouse

- quality department

- distribution

- service department.

This structure fulfils the criteria of functional aggregation 1.

Logistics organization appears first in phases 2P-2C. This unit involves at least the activities connected to physical distribution, and the word "logistics" appears in its name. However, logistics is not considered at strategic level, and activities such as purchasing, inventory management or packaging still belong to the production or sales unit. This is in accordance with functional aggregation 2 .

The average number of employees performing logistics tasks is 8.1 in $2 \mathrm{P}$ and 13.1 in $2 \mathrm{C}$. The most often mentioned tasks were:

- Operative purchasing

- Providing information on suppliers to production

- Material handling

- Packaging, finishing

- Providing information on production to warehouse
- Inventory management

- Providing information on stocks to sales

- Commission

- Distribution

- Return goods handling

- Waste handling

For phases $3 \mathrm{P}$ and $3 \mathrm{C}$ we do not have statistically relevant results due to the small number of companies, but both of the two companies of these phases have logistics unit. The number of companies in the rest of the phases is still small to draw significant conclusions, but we have found that 15 out of the 16 companies have organizational unit dedicated to logistics, and in phases $5 \mathrm{P}-5 \mathrm{C}$ all companies have process organization (stage 4 in the Bowersox model). 
For logistics activities, we found that the first activities carried out by the logistics unit belong to physical distribution, while planning and control of logistics processes stay in the hands of top management or controlling even in higher levels of growth. Only 2 companies of the phases 5P and 5C delegated these tasks to the logistics organization.

Overall, the results of the survey confirmed the parallelism of the two models in case of the stages where the number of companies was sufficient for statistical analysis. In the case of the other stages characteristics were also in accordance with the Bowersox model.

\section{DISCUSSION}

As the result of this study that we determined the stage of development and the typical organizational structure of company logistics along the Greiner model. The configurations given by Bowersox et al. (2002) proved to be suitable as a basis for possible structures of logistics organization. The assumed parallelism between the growth phases of the Greiner model and the stages of development of logistics organization defined by Bowersox was validated by the survey data, so a correspondence between the two models was made.

This parallelism can be used in further scientific or practical analysis of company logistics. If a company is assigned to one phase in the Greiner model, a typical structure of logistics organization can be defined for it. This can help managers for example in the following situations:

- Taking up new activities, especially activities involving logistics-related tasks. These new tasks can be assigned to existing organizational unit more easily. Taking into consideration the actual development stage of the logistics function helps to create a functionally consistent organization.

- Rapid growth of employee number, which often leads to inconsiderate enlargement of existing organization according to the literature of growth models. The joint model can give an idea on which unit is to be enlarged or when new units are to be created.

- Recognizing the necessity organizational changes becomes easier if the manager constantly monitors the growth phase of his/her company.

- When the management plans the reorganization of processes, the joint model can help to select the most suitable organizational solutions. It provides that the new organization will harmonize with the growth phase of the company, which helps to eliminate the symptoms of crisis periods.

The joint model can also be a good tool for management consultants regarding the same management problems.

There are some limitations of this study as well. The sample used for our survey shows distortion compared to the population in its parameters (age and size) in favour of larger companies. Although these companies were overrepresented in the sample, the members of the late growth phases did not reach the number that would have made statistical results significant. For the complete verification of the joint model further surveys should be made on more developed companies (3P and upwards).

Fitting affiliates of multinational companies into a growth or lifecycle model designed for organic growth is also a problematic point of this research. These are large, important but young companies, therefore they do not fit into the growth models, which are all created for organic development. The involvement of these companies in a growth model can be a way of the renewal or expansion of the original models. 


\section{CONCLUSION}

The most important result of this study is the linkage between the stage of development and the typical organizational structure of company logistics along the Greiner model. As a basis for possible structures of logistics organization, we took the configurations given by Bowersox et al. (2002). In the course of the survey, we found a parallelism between the growth phases of the Greiner model and the stages of development of logistics organization defined by Bowersox. The survey data validated the correspondence between the two models. This parallelism can be used in further scientific or practical analysis of company logistics: if a company is classified in the Greiner model, a typical structure of logistics organization can be defined for it.

\section{REFERENCES}

1. Adizes I. (1992): Vállalatok életciklusai. HVG Rt., Budapest. p 350.

2. Baird, L. -Meshoulam, I. (1988): Managing two fits of strategic human resource management. Academy of Management Review, 13, pp.116-128.

3. Bowersox, D. J. - Closs, D. J. - Cooper, M. B. (2002): Supply Chain Logistics Management. McGraw-Hill, New York. p. 656.

4. Churchill, N. C. - Lewis, V. L. (1983): The five stages of small business growth. Harvard Business Review 1983 May-June. p. 11.

5. Frazelle, E. H. (2002): Supply Chain Strategy - The Logistics of Supply chain management. McGraw-Hill, New York. p. 358.

6. Göbölös Á. - Gömöri K. (2004): A vállalati életciklus modellről. Vezetéstudomány 2004/10. p.41-50

7. Greiner, L. E. (1972): Evolution and Revolution as Organizations Growth. HBR JulyAugust 1972, pp. 37-46.

8. Greiner, L. E. (1998). Revolution is still inevitable. Harvard Business Review, 76(3), p.64-65.

9. Hurst, D. K. (1995): Crisis and Renewal: Ethical Anarchy in Mature Organizations. Business Quarterly 1995 Winter. p $33-40$.

10. Kazanjian, R. K. (1988): Relation of dominant problems to stages of growth in technology based new ventures. Academy of Management Journal, 31. p.257-280.

11. Lambert, D. M. - Stock, J. R. - Ellram, L. M. (1998): Fundamentals of Logistics Management. McGraw-Hill, New York. pp 622.

12. Miller, D. - Friesen, P. H. (1984): A longitudinal study of the corporate life cycle. Management Science, 30, p.1161-1184.

13. Milliman, J. - Von Glinow, M.A. - Nathan, M. (1991): Organizational life cycles and strategic international human resource management in multinational companies: implications for congruence theory. Academy of Management Review 16 (2) p.318-330.

14. Miskolczi, M - Gábriel, M: Finding the Logistics Organization That Fits Using Fuzzy Logic. In Acta Technica Jaurinensis Series Logistica. p.343-354. Széchenyi István University Györ 2008. ISSN 1789-6932

15. Miskolczi, M - Gábriel, M: Método de Clasificación con Lógica Difusa para los Modelos de Crecimiento de la Empresa y la Invesigación de una Muestra de Empresas Húngaras. www.monografias.com 2012

16. Quinn, R. E. - Cameron, K. (1983): Organizational life cycles and shifting criteria of effectiveness: Some preliminary evidence. Management Science, 29(1), p.33-52. 
17. Rushton, A. - Croucher, P. - Baker, P. (2006): The Handbook of Logistics and Distribution Management. Kogan Page, London. pp.640.

18. Tatár E. - Dunay A. - Vigh, K. - Illés, Cs. B. (2012): Lifecycle model theories in practice - A management tool for small and medium enterprises. Proceedings of the International Conference on Management of Human Resources 2012. Gödöllö. p.77-83

19. Timmons, J. (1990): New Venture Creation: Entrepreneurship in the 1990s. Homewood, IL: Irwin. pp.677. 